\title{
Multi-criteria assessment of potential regions for wind power generation in the State of Rio de Janeiro
}

\section{Avaliação multicriterial de regiões potenciais para a geração eólica de energia no Estado do Rio de Janeiro}

\begin{abstract}
Elias Rocha Gonçalves Júnior ${ }^{1}$ (D), Igor Cassiano Rangel ${ }^{1}$, Allysson Rodrigues Teixeira Tavares ${ }^{1}$, Elias Gomes Figueira Júnior ${ }^{1}$, Milton Erthal Junior ${ }^{1}$, Claudio Luiz Melo de Souza ${ }^{1}$
${ }^{1}$ Universidade Candido Mendes - UCAM, Centro de Pesquisa Candido Mendes, Campos dos Goytacazes, RJ, Brasil. E-mail: eliasrgjunior1@gmail.com; igorcrangel@gmail.com; allysson.tavares@iff.edu.br; figorj@hotmail.com; miltonerthal@hotmail.com; claudiomelo.edu@gmail.com

How to cite: Gonçalves Júnior, E. R., Rangel, I. C., Tavares, A. R. T., Figueira Júnior, E. G., Erthal Junior M. \& Souza, C. L. M. (2020). Multi-criteria assessment of potential regions for wind power generation in the State of Rio de Janeiro. Gestão \& Produção, 27(3), e4747.

https://doi.org/10.1590/0104-530X4747-20

\begin{abstract}
Due to the current climatic conditions and concerns about the energy generation by renewable sources, wind energy becomes an alternative to meet the existing energy demand. This paper aims to analyze the most promising regions of the State of Rio de Janeiro for the implementation of wind farms for electricity generation. As an analysis tool, we intend to use the Analytic Hierarchy Process (AHP), due to its practicality, to assist in the state's wind power atlas regions evaluation, identifying generating farms installation feasibility based on logistical, technical and economic aspects. Three suitable regions for wind farms installation were evaluated according to the following criteria: potencial for generation, land cost, interconnection cost to the grid, implementing zones e terrain-landform logistics. It was found that, for the Serrana Region, it is indicated the installation of a wind farm that operates at 50 meters in height, because it only has enough potential for equipment with this height. In the Lakes Region, it is appropriate to use wind turbines of 75 meters in height, highlighting it as the most promising for this equipment height, besides having the best logistics capacity of the three regions. Because it has a greater potential area than the other, the North Region provides a greater total production, also taking into account its greater efficiency in the aerogenerators to 100 meters of height, considering this region as the most appropriate. It is worth highlighting that, in this region, there is potential for installation in all the heights presented, scrutinizing the results obtained.
\end{abstract}

Keywords: Renewable energy; Wind energy; Multiple-criteria decision analysis; Analytic hierarchy process; State of Rio de Janeiro.

Resumo: Devido às condições climáticas atuais e preocupações quanto à geração de energia por fontes renováveis, a energia eólica torna-se uma alternativa para atender a demanda energética existente. O objetivo deste trabalho é analisar as regiões mais promissoras do Estado do Rio de Janeiro para implantação de parques eólicos geradores de energia elétrica. Como

Received Mar. 29, 2018 - Accepted Sept. 19, 2018

Financial support: PROSUP/CAPES. The aid for the fees' payment was granted to the author Elias Rocha Gonçalves Júnior, while a postgraduate student at Universidade Candido Mendes, by the Coordination for the Improvement of Higher Education Personnel, through the Regulation of the Support Program for the Postgraduate Studies of Private Education Institutions - PROSUP, document attached to Ordinance No. 181 of Capes, of December 18, 2012. 
ferramenta de estudo, pretende-se utilizar o Método de Análise Hierárquica (AHP), devido à sua praticidade, para auxiliar na avaliação das regiões no atlas eólico do estado identificando a viabilidade de instalação de plantas geradoras com base em aspectos logísticos, técnicos e econômicos. Três regiões aptas à instalação de parques eólicos foram avaliadas segundo os seguintes critérios: potencial gerador, custo do terreno, custo de interligação à rede, espaços para implementação e logística do terreno-relevo. Contatou-se que para a Região Serrana, indica-se a instalação um parque eólico que opere a 50 metros de altura, pois esta possui potencial suficiente apenas para equipamentos com esta altura. Na região dos Lagos, o indicado é que se utilize aerogeradores de 75 metros de altura, destacando-a como a mais promissora para a esta altura de equipamento, além de possuir a melhor capacidade logística das três áreas. Por ter uma área potencial mais extensa que as demais, a região Norte proporciona uma produção total maior, também levando em consideração sua maior eficiência nos aerogeradores a 100 metros de altura, considerando esta região como a mais adequada. Cabe destacar que, nesta região, há potencial para instalação em todas as alturas apresentadas, esquadrinhando os resultados obtidos.

Palavras-chave: Energias renováveis; Energia eólica; Análise multicritério à decisão; Método de análise hierárquica; Estado do Rio de Janeiro.

\section{Introduction}

An important challenge nowadays is to supply the energy demand avoiding aggression to the environment. According to Pereira et al. (2012), the world is mainly consuming fossil fuel energy and, in the case of final energy consumption, this corresponds to $79 \%$ of the world energy matrix. In this context, the conventional processes electric energy generation are among the main responsible for greenhouse gas emissions (Pazheri et al., 2014).

Renewable energies are becoming in some nations the main strategy to mitigate climate change, as result of atmospheric pollutants from industrial activities (Akella et al., 2009). Despite demonstrating innumerous advancements, changes in climatic, ecological and social bases will probably occur with catastrophic effects on living beings (Allen \& Varga, 2013).

To measure the extent of the importance of these incentives for wind energy in the Brazilian case, Dalmaz et al. (2008) indicate the Incentive Program for the Electric Energy Alternative Sources (Programa de Incentivo às Fontes Alternativas de Energia Elétrica - PROINFA), with the objective of encouraging the renewable sources participation. For this purpose, there are auctions and currently finances about $95 \%$ of the projects (Silva et al., 2016).

Renewable energy projects are generally classified as sustainable investments and "environmental friends" (Davidsson et al., 2012). However, all execution activities of a new product concept impact the environment and, in the same way, occur in a new power generation venture conception.

Multicriteria decision methods (MCDM) are often used to solve problems related to site selection for wind farms installation, which generally include complex criteria (Latinopoulos \& Kechagia, 2015). The MCDM most used in solving this type of problem are the Analytic Network Process (ANP), the ELECTRE method, the Technique for Order of Preference by Similarity to Ideal Solution (TOPSIS) and the Analytic Hierarchy Process (AHP) (Yunna \& Geng, 2014). The AHP provides not only the site classification under a general goal, but also provides the rankings under the sub-goals and the evaluation attributes, in order to ensure decision-making reasonableness (Saaty, 
1990), besides being more used method in sustainable energy studies (Pohekar \& Ramachandran, 2004).

This paper aims to analyze the most promising regions of the State of Rio de Janeiro for the implementation of wind farms for electricity generation. As an analysis tool, we intend to use the Analytic Hierarchy Process (AHP), due to its practicality, to assist in the state's wind power atlas regions evaluation, identifying generating farms installation feasibility based on logistical, technical and economic aspects.

Based on research similarity, the paper developed by Ali et al. (2017) is the one closest to the proposal presented in this study regarding the methods used. Both used the AHP method to select suitable sites for the installation of wind farms. The papers' hierarchical model is similar in terms of the criteria structure used, like cost of interconnection to the grid, potential for generation and terrain-landform logistics. Ali et al. (2017) also include the criteria: wind speed, wind power density and population density, on the other hand, this paper includes the criteria: implementing zones and land cost. The main contribution of this work is the proposal of the criteria matrix and the problem focus, which, besides proposing the most suitable place for the implantation of a generating unit, includes the analysis of wind turbines best height, information obtained from regional data (Rio de Janeiro, 2002).

\section{Literature review}

\subsection{Wind energy}

Among these energy sources called "clean", i.e., that do not involve any combustion process or thermal transformation step, wind energy is considered the most promising renewable energy source in Brazil, because several studies indicate considerable values for a high performance of this type of energy (Costa \& Lyra, 2012). This outstanding role is due to the potential it has shown in terms of production costs, safety, energy supply and, above all, environmental sustainability (Martins et al., 2008). More than $54 \mathrm{GW}$ of wind power was installed across the global market in 2016, which now comprises more than 90 countries, including 9 with more than 10,000 MW installed and 29 that have now passed the 1,000 MW mark, with accumulated capacity growing $12.6 \%$ to reach a total of $486.8 \mathrm{GW}$ (Global Wind Energy Council, 2016).

For wind energy to be considered technically feasible, it is necessary that its density is greater than or equal to $500 \mathrm{~W} / \mathrm{m}^{2}$, at a height of $50 \mathrm{~m}$, which requires a minimum wind speed of 7 to $8 \mathrm{~m} / \mathrm{s}$ (Grubb \& Meyer, 1993). Wind energy is widely applicable because wind resources are available in most countries (Wolsink, 2000) and it is estimated that the wind generation cost is lower than that of generation using conventional sources, such as hydropower and natural gas, when taking into account the entire socio-environmental context of installing generation technologies throughout their entire life cycle (Jong et al., 2013)

In order to distinguish which regions are more attractive for the installation of new wind farms, Madlener et al. (2009) affirms that several determining aspects, being these economic, technical, social and environmental, should be taken into account in decision support models. Thus, the decision cannot be based solely on a single dimensional axis of evaluation, such as cost or benefit, and in most cases multiple criteria are used, which in some cases are conflicting in nature and inherent to the decision. 
With the exception of hydropower, wind power is closer to commercial profitability than any other renewable source, although improving the project economy is a vital challenge for wind energy in terms of price, environmental effects and usability (Reiche \& Bechberger, 2004). It offers a commercially intelligent opportunity to fit the prerequisites set for energy services, especially for developing regions, and will produce jobs for local public and industrial trade from the point of view of production (Baloch et al., 2016).

The construction phase is the critical phase in terms of socio-environmental impacts produced by a wind power plant, even negative impacts during installation being relatively small when compared to those produced by conventional sources of energy, such as a hydroelectric plant that demand major civil construction works (Pinto et al., 2017). Nevertheless, the impacts generated must be observed, evaluated and mitigated when possible (Amponsah et al., 2014), from a specific planning and through new technologies usage (Dutra \& Szklo, 2008).

\subsection{AHP method}

The Analytic Hierarchy Process multicriteria method (AHP) emerged in the late 1960s, developed by the mathematician Thomas L. Saaty, when he worked for the Arms Control and Disarmament Agency of the American State Department. Its origin was due to Saaty's observation about the difficulty of communication between the members of the American government and the motivation appeared to develop a decision making support method (Forman \& Selly, 2002).

According to Saaty (1990), the human being has difficulties to examine several restrictions at the same time, even in small quantity. Because of this, the AHP method simplifies the decision-making process, because it allows a complex problem to be divided into several smaller problems, facilitating the understanding and solution of the major one.

The decision-making process through multicriteria analysis has the objective of treating a complex problem in a simple way. In addition, Multicriteria Decision Support methods have the characteristic of recognizing the inherent subjectivity of decision-making problems and using value judgment as a way of treating it scientifically (Costa, 2006).

This is characterized by its simplicity and robustness, allowing its application to extend to several areas, such as: supplier selection for companies (Żak \& Galińska, 2018), total productive maintenance pillars classification (Shinde \& Prasad, 2017), water management assessment in irrigation districts (Sun et al., 2017), supply chain risk assessment framework mounting (Dong \& Cooper, 2016), site selection of an Emergency Care Unit (Briozo \& Musetti, 2015), project analysis (Gartner et al., 1998), prioritization of assets decommissioning in public bodies (Rosa et al., 2018) and in the analysis of the Brazilian electric power generation system (Gomes et al., 2017).

In addition, the AHP method has been applied substantially in research areas related to renewable energy, such as installation site selection, projects and also equipment evaluation (Yunna \& Geng, 2014). Souza et al. (2018) analyzed, by means of an AHP-TOPSIS-2N hybrid multicriteria model, the results obtained by a company's information technology governance committee, which was in strategic realignment process in the triage and prioritization of its portfolio of IT and energy investment projects. Watson \& Hudson (2015) elaborated a multicriteria decision-making structure incorporating the Analytic Hierarchy Process (AHP), which is an innovative approach to this type of study, associated with geographic information system (GIS), to carry out the selection of feasible sites to wind and solar generating farms installation in the United Kingdom. Solangi et al. (2018) used factor analysis (FA) to evaluate technical- 
economic and socio-political aspects, and a hybrid hierarchy process (AHP) and Fuzzy technique to determine the preference order by similarity for the ideal solution (FTOPSIS) to site classification and prioritization for wind energy projects installation in the southeast region of Pakistan.

In order to establish the criteria and identify the alternatives, a hierarchical approach is used by comparing the criteria with each other and establishing a value, from 1 to 9 , according to the importance one represents in relation to the other (Chart 1) (Holder, 1990). These values represent a semantic scale of 5 levels and 4 intermediaries, because if the expert doubts about the degree of importance, the intermediate values can be adopted.

Chart 1. Values assigned description in the AHP scale for comparison in pairs.

\begin{tabular}{|c|c|}
\hline $\begin{array}{l}\text { Assigned } \\
\text { value }\end{array}$ & Importance factor \\
\hline 1 & Equal importance: the criteria contribute equally to the objective. \\
\hline 3 & Moderate Importance: One criterion is slightly more important than the other. \\
\hline 5 & Fundamental importance: One criterion is obviously more important than the other. \\
\hline 7 & $\begin{array}{c}\text { Noted importance: a criterion is clearly demonstrated and its prominence was verified in } \\
\text { practice. }\end{array}$ \\
\hline 9 & Excessive importance: the indications that distinguish the criteria are the most absolute. \\
\hline $2-4-6-8$ & Intermediary values: in case of a doubt by the expert regarding the degree of importance. \\
\hline
\end{tabular}

A hierarchical criteria objectives and alternatives scale is a good reality model, which can bring advantages. The hierarchical representation of a system can be used to obtain an overview of a system and also to describe how changes in priorities at the highest levels affect lower levels priority (Greco et al., 2016). This is the search for solving the problem through the interactions between the different hierarchical levels, not only between elements of the same level (Ke et al., 2012).

The AHP method hierarchical structure facilitates the understanding of a problem and allows observing how the changes in priorities in the higher levels affect lower levels priorities (Vargas, 2010). Hierarchical models are stable and flexible (non-sequential): stable, because small modifications have small effects; flexible, because additions to a wellstructured hierarchy do not disrupt their overall performance (Silva, 2007).

\section{Methodology}

The multicriteria decision support method chosen to carry out this study is the Analytic Hierarchy Process (AHP). This paper will address economic, technical and logistical aspects relevant to the project viability. Social and environmental aspects will be detailed in future researches, specifically for the areas identified as most promising by this study.

\subsection{Potential areas description}

Wind predominance considered favorable in the coastal regions where the highest density of transmission lines, due to large urban centers proximity and which, together with the dense local road network, have a favorable impact on reducing wind projects cost and impacts. 
The state of Rio de Janeiro has prominence areas in terms of wind potential, with a total of three zones optimum for eolic-electrical ventures, being the North region, the Lakes region and the Serrana region, these being represented in the areas with numbers 1,2 and 3 , respectively (Figure 1 ).

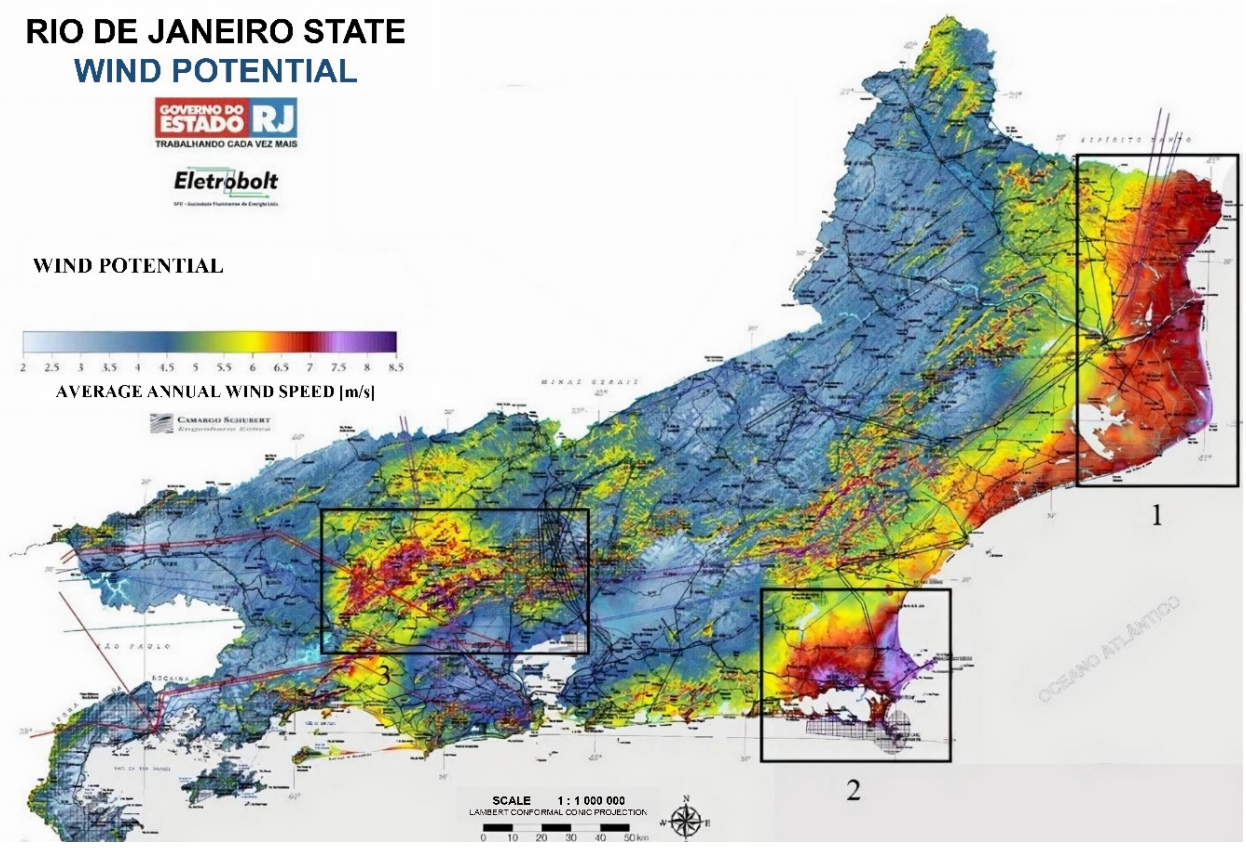

Figure 1. Potential areas in the State of Rio de Janeiro. Source: Rio de Janeiro (2002).

The wind potential map presented in the Wind Atlas of the State of Rio de Janeiro (2002) highlights the three main areas for eolic-electric projects in the state.

\subsubsection{North region}

Extensive coastal plain, with low roughness and wind regimes favorable to wind farms, average annual speed around $6.5 \mathrm{~m} / \mathrm{s}$ (50 meters in height) in the best places. Area with relatively low population density and farthest from large substations, having a vocation for large wind farms (tens to hundreds of Megawatts), which are necessary to dilute the interconnection costs to the regional system.

\subsubsection{Lakes region}

Coastal area, great tourist appeal, with relatively high population density and close to medium and large substations, average annual speed around $7.0 \mathrm{~m} / \mathrm{s}$ (50 meters in height) in the best places. Presents a vocation for wind power plants from tens to hundreds of Megawatts dispersed among existing geographic opportunities. In addition to tending the situation of higher land cost for this type of project, but presents lower interconnection costs to the electric system. 


\subsubsection{Serrana region}

It presents some areas suitable for small to medium sized farms (up to a few tens of Megawatts), average annual speed around 6.0 to $6.5 \mathrm{~m} / \mathrm{s}$ in the best places, exceeding $7.5 \mathrm{~m} / \mathrm{s}$ in the highest elevations. Because of the complex landform, there may be potential access difficulties for of turbines transportation and assembly interconnection to the electrical system and possibly distant substations.

\subsection{Definition of evaluation criteria}

The cities with the highest wind potential in each region mentioned above will be used for analysis, which are listed in Table 1.

Table 1. Cities with the highest potential in each area under study.

\begin{tabular}{ccc}
\hline Area & Region & Cities \\
\hline 1 & North & Campos dos Goytacazes, São Francisco de Itabapoana and São João da Barra. \\
2 & Lakes & Cabo Frio, Araruama, São Pedro da Aldeia, Saquarema, Armação dos Búzios, \\
& Rio das Ostras and Arraial do Cabo. \\
\hline 3 & Serrana & Petrópolis, Piraí, Paracambi, Vassouras, Mendes and Miguel Pereira. \\
\hline
\end{tabular}

Source: Adapted from Governo do Estado do Rio de Janeiro (2002).

After an interaction phase of the decision-maker with experts, the criteria that mirror the defined objectives were identified, in the search to establish those most relevant in the context considered. The criteria considered were the potential for generation of the lease, land cost for the generating plant implantation, interconnection cost to the electric system and the logistic access for the implementation and operation, represented in Chart 2.

Chart 2. Criteria considered for the analysis.

\begin{tabular}{|c|c|c|}
\hline Criteria & Justification & Preference direction \\
\hline $\begin{array}{c}\text { Potential for } \\
\text { generation } \\
\text { (Janke, 2010) }\end{array}$ & $\begin{array}{c}\text { The factor that directly influences the } \\
\text { venture, since it is the source and the } \\
\text { intensity for the project success. }\end{array}$ & $\begin{array}{c}\text { The higher the wind / solar } \\
\text { potential, the more energy can be } \\
\text { generated (maximization). }\end{array}$ \\
\hline $\begin{array}{c}\text { Land cost } \\
\text { 2015) }\end{array}$ & $\begin{array}{c}\text { The land cost is a criterion that } \\
\text { influences the value of the project } \\
\text { installation (rent or purchase). }\end{array}$ & $\begin{array}{c}\text { The lower the land value, the lower } \\
\text { the project cost (minimization). }\end{array}$ \\
\hline $\begin{array}{c}\text { Interconnection } \\
\text { cost to the grid } \\
\text { (Baban \& Parry, } \\
\text { 2001) }\end{array}$ & $\begin{array}{c}\text { The project installation costs and the } \\
\text { generated energy transmission vary } \\
\text { according to installation region distance } \\
\text { from the transmission lines. }\end{array}$ & $\begin{array}{c}\text { The lower the distance from the } \\
\text { transmission lines, the lower } \\
\text { installing costs of new energy } \\
\text { transmission lines (minimization) }\end{array}$ \\
\hline $\begin{array}{c}\text { Implementing } \\
\text { zones (Janke, } \\
\text { 2010) }\end{array}$ & $\begin{array}{c}\text { The potential area is influenced by the } \\
\text { venture installation distance in relation } \\
\text { to the roads and wind speed. }\end{array}$ & $\begin{array}{c}\text { The greater the power of the } \\
\text { available space and the ease of } \\
\text { implementation, the lower the cost } \\
\text { and the better is the performance } \\
\text { (maximization). }\end{array}$ \\
\hline $\begin{array}{c}\text { Terrain-landform } \\
\text { logistics } \\
\text { (Baban \& Parry, } \\
\text { 2001) }\end{array}$ & $\begin{array}{c}\text { The logistical aspects of terrain, slope, } \\
\text { for example, can cause technical } \\
\text { installation difficulties, as well as reduce } \\
\text { the wind/solar potential of the area. }\end{array}$ & $\begin{array}{c}\text { The more flat the farm and its } \\
\text { surroundings relief, the easier the } \\
\text { logistical access (maximization). }\end{array}$ \\
\hline
\end{tabular}

Source: Prepared by the authors. 
The existence of more than one point of view to be considered for the comparison between a group of alternatives or, as in this study, determining the superiority of one alternative over the other, which can be quite a complex task, that demands tools usage capable of solving this type of question and justifies the use of the AHP method to indicate which of the three regions is most promising in relation to the analyzed variables.

\subsubsection{Potential for generation}

According to the Wind Atlas of the State of Rio de Janeiro (2002), the minimum thresholds of attractiveness for investments in wind energy generation depend on the economic and institutional contexts of each country, varying, in average annual speed, between $5.5 \mathrm{~m} / \mathrm{s}$ and $7.0 \mathrm{~m} / \mathrm{s}$. Technically, annual averages from $6.0 \mathrm{~m} / \mathrm{s}$ already constitute favorable conditions for wind farms operation.

This study will consider annual averages above $6.0 \mathrm{~m} / \mathrm{s}$, for the different heights analyzed, as a minimum condition of attractiveness for wind farms implementation. The potential for generation of each studied area will then be obtained through the cumulative annual energy value, divided by the respective cumulative area for each height range, from $6.0 \mathrm{~m} / \mathrm{s}$. Table 2 shows the sum of the installable potentials for average speeds above $6.0 \mathrm{~m} / \mathrm{s}$.

Table 2. Annual potential of the studied regions at heights of 50, 75 and 100 meters.

\begin{tabular}{ccccc}
\hline Region & $\begin{array}{c}\text { Height } \\
(\mathbf{m})\end{array}$ & Area $\left(\mathbf{K m}^{2}\right)$ & Potential/Area $\left(\mathbf{G W h} / \mathbf{K m}^{2}\right)$ & $\begin{array}{c}\text { Total Annual Potential } \\
(\mathbf{G W h})\end{array}$ \\
\hline \multirow{3}{*}{ North } & 50 & 1844 & 3.61 & 995.00 \\
\cline { 2 - 5 } & 75 & 3335 & 4.12 & $6,273.00$ \\
\cline { 2 - 5 } & 100 & 3908 & 4.24 & $12,300.00$ \\
\multirow{2}{*}{ Lakes } & 50 & 886 & 3.85 & $1,613.00$ \\
\cline { 2 - 5 } & 75 & 1566 & 4.41 & $3,848.00$ \\
\hline \multirow{3}{*}{ Serrana } & 100 & 2130 & 4.51 & $5,425.00$ \\
\cline { 2 - 5 } & 50 & 576 & 3.94 & $1,145.00$ \\
\cline { 2 - 5 } & 100 & 1484 & 4.26 & $2,289.00$ \\
\hline
\end{tabular}

Source: Adapted from Governo do Estado do Rio de Janeiro (2002).

\subsubsection{Land cost}

An important indicator for the economic feasibility analysis of a venture of this nature is renting or purchasing cost of the land where the wind turbines will be installed. This work will take as a basis the Naked Earth Value (NLV) of the studied areas (Table 3), which is updated every year by the Secretariat of Agriculture, Livestock, Fisheries and Supply of the State of Rio de Janeiro and published in the Official State Gazette.

The Naked Land Value (NLV), calculation basis of the Tax on Rural Territorial Property, is the property's market, excluding constructions, facilities and improvements, permanent and temporary crops, cultivated and improved pastures, and planted forests. 
Table 3. Average Naked Land Value of the North, Lake and Serrana regions.

\begin{tabular}{|c|c|c|c|}
\hline Region & Cities & R\$ / Hectare & R\$ Average / Hectare \\
\hline \multirow{3}{*}{ North } & Campos dos Goytacazes & $3,870.00$ & \multirow{3}{*}{$3,495.00$} \\
\hline & São Francisco de Itabapoana & $2,935.00$ & \\
\hline & São João da Barra & $3,680.00$ & \\
\hline \multirow{7}{*}{ Lakes } & Cabo Frio & $2,420.00$ & \multirow{7}{*}{$2,420.00$} \\
\hline & Araruama & $2,420.00$ & \\
\hline & São Pedro da Aldeia & $2,420.00$ & \\
\hline & Saquarema & $2,420.00$ & \\
\hline & Armação de Búzios & $2,420.00$ & \\
\hline & Rio das Ostras & $2,420.00$ & \\
\hline & Arraial do Cabo & $2,420.00$ & \\
\hline \multirow{6}{*}{ Serrana } & Petrópolis & $2,420.00$ & \multirow{6}{*}{$1,932.50$} \\
\hline & Piraí & $1,905.00$ & \\
\hline & Paracambi & $2,420.00$ & \\
\hline & Vassouras & $1,905.00$ & \\
\hline & Mendes & $1,320.00$ & \\
\hline & Miguel Pereira & $1,625.00$ & \\
\hline
\end{tabular}

Source: Adapted from Governo do Estado do Rio de Janeiro (2017).

\subsubsection{Interconnection cost to the grid}

During the project phase, soil studies and infrastructure for energy supply are carry out, with respect to the distance to the nearest substation and the logistic plan for distribution of electricity generated. When analyzing the electric system map of the State of Rio de Janeiro (Figure 2), it is noticed that the Lakes region is the one that has the closest proximity between the areas with a wind vocation and the electric. Despite having relative proximity to the electric grid, the rugged landform of the Serrana region raises the costs of interconnection and construction of access facilities.

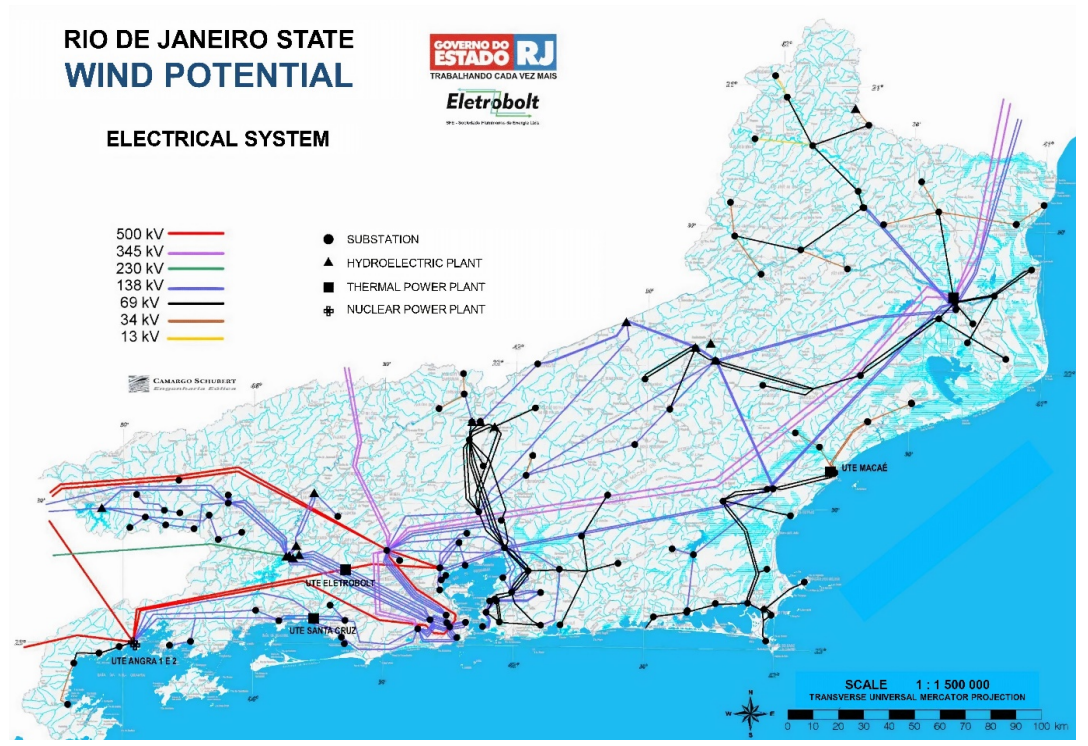

Figure 2. Electrical Grid of the State of Rio de Janeiro. Source: Rio de Janeiro (2002). 
As all the areas studied are very broad, the concentration of generating plants and/or substations in each of the established regions was used as base, with the purpose of quantifying the criterion of interconnection to the distribution grid, shown in Table 4.

Table 4. Power Plants and/or Substations quantification by Region.

\begin{tabular}{ccccc}
\hline Area & Region & Power plants & Substations & Total \\
\hline 1 & North & 1 & 10 & 11 \\
\hline 2 & Lakes & 0 & 12 & 12 \\
3 & Serrana & 3 & 11 & 14 \\
\hline
\end{tabular}

Source: Adapted from Governo do Estado do Rio de Janeiro (2002).

\subsubsection{Implementing zones}

Each of the regions has favorable and unfavorable locations for wind farm installation. Larger zones provide for the possibility of a larger number of wind turbines installations and, consequently, present a greater expansion possibility and energy production for the industry. Based on the potential wind power table of each region (Table 2), the size of these potential areas was extracted, whose winds have a speed greater than $6.0 \mathrm{~m} / \mathrm{s}$. The cumulative values are shown in Table 5 .

Table 5. Suitable zones delimitation for wind turbines installation according to height.

\begin{tabular}{ccc}
\hline Region & Height $\mathbf{( m )}$ & Available zone $\mathbf{( K m}^{\mathbf{2}} \mathbf{)}$ \\
\hline \multirow{3}{*}{ North } & 50 & 1844 \\
& 75 & 3335 \\
\cline { 2 - 3 } & 100 & 3908 \\
\cline { 2 - 3 } & 50 & 886 \\
\cline { 2 - 3 } & 75 & 1566 \\
\hline \multirow{2}{*}{ Serrana } & 100 & 2130 \\
& 50 & 576 \\
\cline { 2 - 3 } & 75 & 1050 \\
\hline
\end{tabular}

Source: Adapted from Governo do Estado do Rio de Janeiro (2002).

\subsubsection{Terrain-landform logistics}

Once you have the project approved, the company responsible for the wind farm will start the installation of the necessary equipment for its operation. Previously the wind turbines installation, it is necessary to perform cleaning the land and earthworks, with leveling and paving of access to wind turbines. The second step is staking, which consists of placing stakes in the towers bases for their interconnection to the ground, where, later, they are incorporated to the block of the foundation, giving support to the tower of the aerogenerator.

Considering the logistic aspects for the operation and assembly of the ventures, it is noticed that the Lakes and North regions are favored by the flat landform, road mesh and port access. The rugged landform of the Serrana region and port absence put it at a disadvantage in relation to installation, assembly and operation logistics. 
In view of this, the process used to measure the criterion was to establish different weights according to the existing logistical resources and to quantify them in each of the regions. These data are presented in Table 6.

Table 6. Analysis and classification by weights of each region's landform, road network and port access.

\begin{tabular}{|c|c|c|c|c|c|c|c|c|}
\hline \multirow{2}{*}{\multicolumn{2}{|c|}{ Logistics }} & \multirow{2}{*}{ Weight } & \multicolumn{2}{|c|}{ North } & \multicolumn{2}{|c|}{ Lakes } & \multicolumn{2}{|c|}{ Serrana } \\
\hline & & & Qty. & $\overline{\text { Total }}$ & Qty. & $\overline{\text { Total }}$ & Qty. & Total \\
\hline \multicolumn{2}{|c|}{ Port } & 5 & 1 & 5 & 1 & 5 & 0 & 0 \\
\hline \multirow{2}{*}{ Landform } & Flat & 5 & 1 & 5 & 1 & 5 & 0 & 0 \\
\hline & Rugged & 0 & 0 & 0 & 0 & 0 & 1 & 0 \\
\hline \multirow{2}{*}{ Federal Highway } & Duplicated & 3 & 0 & 0 & 1 & 3 & 3 & 9 \\
\hline & Paved & 2 & 2 & 4 & 2 & 4 & 1 & 2 \\
\hline \multirow{2}{*}{ State highway } & Duplicated & 2 & 0 & 0 & 1 & 2 & 0 & 0 \\
\hline & Paved & 1 & 5 & 5 & 8 & 8 & 12 & 12 \\
\hline \multicolumn{2}{|c|}{ Total } & & \multicolumn{2}{|c|}{19} & \multicolumn{2}{|c|}{27} & \multicolumn{2}{|c|}{23} \\
\hline
\end{tabular}

Source: Prepared by the authors.

\section{Results}

The potential for generation is moderately more important than the implementing zones, because it represents system efficiency, while the potential area defines its capacity. The implementing zones is strongly more importante than the land cost due to tis interference in wind farm's production capacity and the fact that the land cost is capital invested in real state. As the interconnection cost to the grid is a non-returnable cost, the implementing zones is moderately stronger criteron than this one. The logistics has fundamental importance in the installation process of a wind farm, but once installed it will have no greater influence on the process, so the criterion implementing zones is significantly more important than the previous one. Figure 3 shows the criteria hierarchy representation and the study regions.

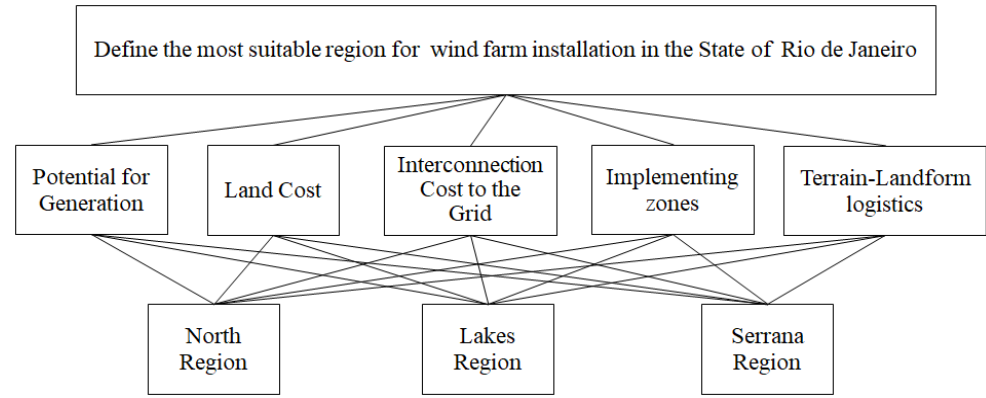

Figure 3. Criteria Hierarchy. Source: Prepared by the authors.

The most important criterion among those studied is the potential for generation, because it defines the system efficiency. As the land cost is a returnable capital and the accessibility has greater interference only in the installation process of the wind farm, the potential for generation ends up being an extremely important criterion than both. The potential for generation has confirmed importance in relation to the 
interconnection cost to the grid, because it can present high costs and does not offer a direct return.

After the system is installed to connect to the distribution grid, all the capital invested in this process has no direct return. In case the wind farm is deactivated, the land can be sold, generating capital, while the towers and cables used in connection with the distribution grid do not have the same destination, becoming lost capital. Because it offers greater risk to capital, the interconnection cost to the grid is moderately stronger than land cost. The Terrain-landform logistics is equally important to the land cost because it presents greater interference only at the time of installation.

Due to the capital risk invested in the interconnection with the distribution grid, this criterion appears to be moderately more important than the logistics aspects. The criteria weights matrix, represented in Figure 4, was elaborated.

\begin{tabular}{|c|c|c|c|c|c|c|}
\hline & $\mathrm{Cl}$ & $\mathrm{C} 2$ & C3 & $\mathrm{C} 4$ & C5 & \\
\hline Cl & 1 & $1 / 3$ & 5 & 3 & 5 & $\mathbf{C l}=$ Implementing zones \\
\hline $\mathrm{C} 2$ & 3 & 1 & 9 & 7 & 9 & C2 $=$ Potential for Generation \\
\hline $\mathrm{C} 3$ & $1 / 5$ & $1 / 9$ & 1 & $1 / 3$ & 1 & $\mathbf{C 3}=$ Land Cost \\
\hline C4 & $1 / 3$ & $1 / 7$ & 3 & 1 & 3 & $\begin{array}{l}\text { C4 }=\text { Interconnection Cost to the Grid } \\
\text { C5 }=\text { Terrain-Landform Logistics }\end{array}$ \\
\hline C5 & $1 / 5$ & $1 / 9$ & 1 & $1 / 3$ & 1 & \\
\hline
\end{tabular}

Figure 4. Criteria weights matrix. Source: Prepared by the authors.

In order to prepare the payment table, the data collection of each criterion for each alternative was realized. Next, the payment table was prepared (Table 7) and the priority aggregation matrix, referring to the criteria analyzed (Figure 4), according to the methodology:

Table 7. Payment table for wind turbines of 50, 75 and 100 meters in height.

\begin{tabular}{|c|c|c|c|c|c|}
\hline 50 meters & $\mathrm{C} 1\left(\mathrm{Km}^{2}\right)$ & C2 (GWh/Km²) & C3 (R\$) & C4 (Number) & C5 (Number) \\
\hline North region & 1,844 & 3.12 & $3,495.00$ & 11 & 19 \\
\hline Lakes region & 886 & 3.429 & $2,420.00$ & 12 & 27 \\
\hline Serrana region & 576 & 3.5 & $1,932.50$ & 14 & 23 \\
\hline Direction & Max & Max & Min & Max & Max \\
\hline 75 meters & $\mathrm{C} 1\left(\mathrm{Km}^{2}\right)$ & C2 $\left(\mathrm{GWh} / \mathrm{Km}^{2}\right)$ & C3 (R\$) & C4 (Number) & C5 (Number) \\
\hline North region & 3,335 & 3.825 & $3,495.00$ & 11 & 19 \\
\hline Lakes region & 1,566 & 4.019 & $2,420.00$ & 12 & 27 \\
\hline Serrana region & 1,050 & 3.859 & $1,932.50$ & 14 & 23 \\
\hline Direction & Max & Max & Min & Max & Max \\
\hline 100 meters & $\mathrm{C} 1\left(\mathrm{Km}^{2}\right)$ & C2 (GWh/Km²) & C3 (R\$) & C4 (Number) & C5 (Number) \\
\hline North region & 3,908 & 4.053 & $3,495.00$ & 11 & 19 \\
\hline Lakes region & 2,130 & 4.072 & $2,420.00$ & 12 & 27 \\
\hline Serrana region & 1,484 & 3.868 & $1,932.50$ & 14 & 23 \\
\hline Direction & Max & Max & Min & Max & Max \\
\hline
\end{tabular}

Source: Prepared by the authors. Legend: $\operatorname{Max}=$ Max; Min = Minimum. 
As seen in Figure 5, the results of the local average priorities consistently reflect the data presented in Table 7. For turbines of $50 \mathrm{~m}$ in height, the Serrana region stands out in the two criteria with the highest weight in the problem: $\mathrm{C} 2$ and C4. In the case of $75 \mathrm{~m}$ high wind turbines, the Lakes region stands out against the alternatives, due to its predominance in the most important criterion among the studied: C2. As for the case of the $100 \mathrm{~m}$ towers, the North region is the most promising of all, with emphasis on criterion $\mathrm{C} 2$, aforementioned as the most important, and $\mathrm{C} 1$, intermediate weight criterion, but relevant in the site selection.

\begin{tabular}{|c|c|c|c|c|c|c|}
\hline 50 meters & $\mathrm{C} 1$ & $\mathrm{C2}$ & $\mathrm{C} 3$ & $\mathrm{C4}$ & C5 & \multirow{5}{*}{$\begin{array}{l}\mathbf{A 1}=\text { North Region } \\
\mathbf{A 2}=\text { Lakes Region } \\
\mathbf{A 3}=\text { Serrana Region }\end{array}$} \\
\hline A1 & 0.7838 & 0.0974 & 0.054 & 0.1365 & 0.1047 & \\
\hline & & & & & & \\
\hline A2 & 0.1349 & 0.3331 & 0.253 & 0.2385 & 0.637 & \\
\hline A3 & 0.0813 & 0.5695 & 0.693 & 0.625 & 0.2583 & \\
\hline 75 meters & $\mathrm{C} 1$ & $\mathrm{C} 2$ & $\mathrm{C} 3$ & C4 & $\mathrm{C5}$ & \\
\hline A1 & 0.7854 & 0.2 & 0.1095 & 0.054 & 0.1047 & \\
\hline A2 & 0.1488 & 0.6 & 0.309 & 0.253 & 0.637 & \\
\hline A3 & 0.0658 & 0.2 & 0.5816 & 0.693 & 0.2583 & \\
\hline 100 meters & $\mathrm{C} 1$ & $\mathrm{C} 2$ & $\mathrm{C} 3$ & C4 & C5 & \\
\hline A1 & 0.7854 & 0.4286 & 0.1095 & 0.054 & 0.1047 & \\
\hline A2 & 0.1488 & 0.4286 & 0.309 & 0.253 & 0.637 & \\
\hline A3 & 0.0658 & 0.1429 & 0.5816 & 0.693 & 0.2583 & \\
\hline
\end{tabular}

Figure 5. Priorities matrix in light of the criteria for wind turbines of 50,75 and 100 meters of height. Source: Prepared by the authors.

In the methodology development, the calculations performed to determine the Consistency Quotient of the matrix of each criterion presented values lower than 0.1, therefore being considered acceptable for the method.

The analysis carried out, presented in Table 8, shows that the Serrana region stands out in wind power production at 50 meters in height, while the Lakes region was superior to the others for 75 meters in height and the North region had the best performance for 100 meters in height.

Table 8. Alternatives prioritization by region for aerogenerators of 50,75 and 100 meters of height.

\begin{tabular}{cccc}
\hline Ranking & $\mathbf{5 0}$ meters & $\mathbf{7 5}$ meters & $\mathbf{1 0 0}$ meters \\
\hline 1 & Serrana region & Lakes region & North region \\
\hline 2 & Lakes region & North region & Lakes region \\
\hline 3 & North region & Serrana region & Serrana region \\
\hline
\end{tabular}

Source: Prepared by the authors.

It was verified that, with annual demand lower than $2000 \mathrm{GWh}$ in the region of Serrana, it is better to install a wind farm that operates at 50 meters in height, being observed as the best region among the three, despite having sufficient potential only 
at this height. If the demand exceeds the amount quoted above, it would be necessary to review the feasibility of using wind energy in the region. In addition, it presents the lowest cost for land purchase and interconnection to the power distribution grid.

In the Lakes region, it is advisable to use wind turbines that operate at 75 meters in height, with a maximum annual production capacity of approximately $6,300 \mathrm{GWh}$, highlighting it as the most promising for this equipment height. Besides that, it was observed that it has the best logistic capacity of the three regions, considering landform, road network and port access.

Because it has a greater potential area than the other, the North region provides a greater total production, also taking into account its greater efficiency in the aerogenerators to 100 meters of height. This region can reach an annual production of around 19,000 GWh, at this height, despite having the highest land and interconnection costs, and reasonable logistic conditions. It should be noted that, in this region, there is potential for installation in all the heights presented, scrutinizing the results obtained.

\section{Discussion}

The present paper approached the use of the AHP method for the selection of which region of the state of Rio de Janeiro is characterized as the most propitious/promising for wind farms installation, considering three different heights, 50, 75 and 100 meters, of the wind turbines. This selection was based on based on logistical, technical and economic aspects relevant to project viability, for five of the various existing indicators, which are Potential for Generation, Land Cost, Interconnection Cost to the Grid, Implementing Zones e Terrain-Landform Logistics.

The method was adequate for the proposed case, because the decision, simply by logic or intuition, would be ineffective in reaching these results, according to Saaty (1990). The facility offered to managers can be noticed by obtaining individual results for each criterion or, in general, by comparing the criteria together, allowing each criterion importance to become clear (Macharis et al., 2004) and supports decisionmakers through the paired comparisons made (Zahir, 1999).

We can highlight as an example the Gargaú Wind Power Plant (Gargaú WPP), the first wind power generating plant in the Southeast Region, located in the North region of the State of Rio de Janeiro. This venture, supported by the Incentive Program for the Electric Energy Alternative (PROINFA), was installed on the Gargaú beach, in the city of São Francisco do Itabapoana and has a total installed capacity of $28.05 \mathrm{MW}$. The Gargaú WPP comprises an area of 430 hectares occupied by 17 wind turbines of $1.65 \mathrm{MW}$, each of them measuring 120 meters in height (Portal Multiempreendimentos, 2013). This project effectively demonstrates that the North Region of the State has real potential for exploration of wind energy generation and indicates that it is in line with the prospects and policies for the wind energy expansion in the countryallowing the definition of an ecological-economic zoning for this type of energy generation (Barbosa Filho \& Azevedo, 2014).

The environmental impacts caused by wind farms depend relatively depend on its location, in which careful design and selection of appropriate sites can mitigate the negative impacts associated with (Kaldellis et al., 2013). A site that does not meet all requirements of a wind farm will affect its efficiency; moreover, the farm's power potential cannot be fully exploited (Ali et al., 2017).

As more renewable energy projects are promoted, the lack of viable facilities will become the main constraint (Grassi et al., 2012), confirming that the selection of 
suitable locations is fundamental for wind farms future development. At the same time that rising populations and modernized economies are pushing the space available for food production (McMichael et al., 2007), housing and environmental protection, renewable energy technologies will be seen as favorable, because fossil fuels usage can be impacted by climate change policies, which will be a major global challenge (Allen \& Varga, 2013).

It should be noted that wind farms construction brings together a complex system of services and improvements in local infrastructure (Araújo, 2014), as specialized construction industry implementation, road network development, associated and outsourced equipment and services industry, green economy promotion, as well as the creation and expansion of local education and research centers. In addition, electricity generation from wind energy has been increasingly inviting, because it does not present the magnitude of the environmental impacts generally associated to other forms of energy use (Kaldellis et al., 2013) and capacity to generate new jobs (Azevedo et al., 2017; Simas \& Pacca, 2013).

\section{Conclusions}

This paper aimed to analyze the most promising regions for wind farms development and implementation in a case study area, the State of Rio de Janeiro, with emphasis on logistical, technical and economic considerations. After the assessment process, it was concluded that the North Region is considered the most suitable for wind power plant installation. Considering all the criteria, it has potential for installation at all heights presented and would provide a greater total production when compared to the other regions under analysis, close to $19,000 \mathrm{GWh}$, at a height of 100 meters, able to meet a larger supply area.

The presented method can be applied in any place with adequate data availability, therefore, could withstand this global trend, albeit with adaptations to suit the local situation. As a suggestion for future researches, it is indicated the analysis continuation with the intention of defining, within the most favorable region in the light of the analyzed criteria, for each of the considered heights, which municipality would be the most appropriate to receive this type of venture, contemplating in its analysis the social and environmental aspects.

\section{Acknowledgements}

The authors thank the Coordination for the Improvement of Higher Education Personnel (Coordenação de Aperfeiçoamento de Pessoal de Nível Superior - CAPES) for the financial support to this research.

\section{References}

Akella, A. K., Saini, R. P., \& Sharma, M. P. (2009). Social, economical and environmental impacts of renewable energy systems. Renewable Energy, 34(2), 390-396. http://dx.doi.org/10.1016/j.renene.2008.05.002.

Ali, Y., Butt, M., Sabir, M., Mumtaz, U., \& Salman, A. (2017). Selection of suitable site in Pakistan for wind power plant installation using analytic hierarchy process (AHP). Journal of Control and Decision, 5(2), 117-128. http://dx.doi.org/10.1080/23307706.2017.1346490. 
Allen, P., \& Varga, L. (2013). Exploring possible energy futures for the UK: evolving power generation. Emergence, 15(2), 24-47.

Alves, J. R. X., \& Alves, J. M. (2015). Definição de localidade para instalação industrial com o apoio do método de análise hierárquica (AHP). Production Journal, 25(1), 13-26. http://dx.doi.org/10.1590/S0103-65132014005000023.

Amponsah, N., Troldborg, M., Kington, B., Aalders, I., \& Hough, R. L. (2014). Greenhouse gas emissions from renewable energy sources: a review of life cycle considerations.

Renewable \& Sustainable Energy Reviews, 39, 461-475. http://dx.doi.org/10.1016/j.rser.2014.07.087.

Araújo, R. C. P. (2014). Análise da atitude dos turistas com relação ao desenvolvimento da energia eólica no litoral Cearense, Brasil. Turismo e Sociedade, 7(2), 308-329. http://dx.doi.org/10.5380/tes.v7i2.35298.

Azevedo, J. P. M., Nascimento, R. S., \& Schram, I. B. (2017). Energia eólica e os impactos ambientais: um estudo de revisão. Revista UniVap, 51, 101-106. http://dx.doi.org/10.18066/revistaunivap.v22i40.714.

Baban, S. M. J., \& Parry, T. (2001). Developing and applying a GIS-assisted approach to locating wind farms in the UK. Renewable Energy, 24(1), 59-71. http://dx.doi.org/10.1016/S0960-1481(00)00169-5.

Baloch, M. H., Kaloi, G. S., \& Memon, Z. A. (2016). Current scenario of the wind energy in Pakistan challenges and future perspectives: A case study. Energy Reports, 2, 201-210. http://dx.doi.org/10.1016/j.egyr.2016.08.002.

Barbosa Filho, W. P., \& Azevedo, A. C. S. (2014) O uso da análise hierárquica como auxílio na tomada de decisão de políticas públicas em energia eólica considerando aspectos de sustentabilidade. In Anais do V Congresso de Energia Solar - CBENS 2014. Recife: Associação Brasileira de Energia Solar.

Briozo, R., \& Musetti, M. (2015). Método multicritério de tomada de decisão: aplicação ao caso da localização espacial de uma Unidade de Pronto Atendimento - UPA 24 h. Gestão \& Produção, 22(4), 805-819. http://dx.doi.org/10.1590/0104-530X975-13.

Costa, G. B., \& Lyra, R. F. F. (2012). Análise dos padrões de vento no estado de Alagoas. Revista Brasileira de Meteorologia, 27(1), 31-38. http://dx.doi.org/10.1590/S010277862012000100004.

Costa, H. G. (2006). Auxilio multicritério à decisão: método AHP. Rio de Janeiro: ABEPRO.

Dalmaz, A., Passos, J. C., \& Colle, S. (2008). Energia eólica para geração de eletricidade e a importância da previsão. Revista ABCM -Engenharia, 13(1), 27-32.

Davidsson, S., Höök, M., \& Wall, G. (2012). A review of life cycle assessments on wind energy systems. The International Journal of Life Cycle Assessment, 17(6), 729-742. http://dx.doi.org/10.1007/s11367-012-0397-8.

Dong, Q., \& Cooper, O. (2016). An orders-of-magnitude AHP supply chain risk assessment framework. International Journal of Production Economics, 182, 144-156. http://dx.doi.org/10.1016/j.ijpe.2016.08.021.

Dutra, R. M., \& Szklo, A. S. (2008). Incentive policies for promoting wind power production in Brazil: scenarios for the Alternative Energy Sources Incentive Program (PROINFA) under the New Brazilian electric power sector regulation. Renewable Energy, 33(1), 65-76. http://dx.doi.org/10.1016/j.renene.2007.01.013.

Forman, E. H., \& Selly, M. A. (2002). Decision by objectives: How to convince others that you are right. Singapore: World Scientific.

Gartner, I. R., Casarotto Filho, N., \& Kopittke, B. H. (1998). Um sistema multicriterial de apoio à análise de projetos em bancos de desenvolvimento. Revista Produto \& Produção, 2(3), 7586. 
Global Wind Energy Council. (2016). Global Wind Report 2016 - Annual market update. Retrieved in 2017, November 10, from http://gwec.net/publications/global-wind-report2/global-wind-report-2016

Gomes, C. F. S., Costa, H. G., \& Barros, A. P. (2017). Sensibility analysis of MCDA using prospective in Brazilian energy sector. Journal of Modelling in Management, 12(3). https://doi.org/10.1108/JM2-01-2016-0005.

Grassi, S., Chokani, N., \& Abhari, R. S. (2012). Large scale technical and economical assessment of wind energy potential with a GIS tool: case study lowa. Energy Policy, 45, 73-85. http://dx.doi.org/10.1016/j.enpol.2012.01.061.

Greco, S., Ehrgott, M., \& Figueira, J. (2016). Multiple criteria decision analysis. New York: Springer Science+Business Media. http://dx.doi.org/10.1007/978-1-4939-3094-4.

Grubb, M. J., \& Meyer, N. I. (1993). Wind energy: resources, systems and regional strategies. In T. B. Johansson, H. Kelly, A. K. N. Reddy \& R. H. Williams (Eds.) Renewable energy: sources for fuels and electricity. Washington: Island Press.

Holder, R. D. (1990). Some comments on the analytic hierarchy process. The Journal of the Operational Research Society, 41(11), 1073-1076. http://dx.doi.org/10.1057/jors.1990.167.

Janke, J. R. (2010). Multicriteria GIS modeling of wind and solar farms in Colorado. Renewable Energy, 35(10), 2228-2234. http://dx.doi.org/10.1016/j.renene.2010.03.014.

Jong, P., Sánchez, A. S., Esquerre, K., Kalid, R. A., \& Torres, E. A. (2013). Solar and wind energy production in relation to the electricity load curve and hydroelectricity in the northeast region of Brazil. Renewable \& Sustainable Energy Reviews, 23, 526-535. http://dx.doi.org/10.1016/j.rser.2013.01.050.

Kaldellis, J. K., Kapsali, M., Kaldelli, E., \& Katsanou, E. (2013). Comparing recent views of public attitude on wind energy, photovoltaic and small hydro applications. Renewable Energy, 52, 197-208. http://dx.doi.org/10.1016/j.renene.2012.10.045.

Ke, G. Y., Li, K., \& Hipel, K. W. (2012). An integrated multiple criteria preference ranking approach to the Canadian west coast port congestion conflict. Expert Systems with Applications, 39(10), 9181-9190. http://dx.doi.org/10.1016/j.eswa.2012.02.086.

Latinopoulos, D., \& Kechagia, K. (2015). A GIS-based multi-criteria evaluation for wind farm site selection. a regional scale application in Greece. Renewable Energy, 78, 550-560. http://dx.doi.org/10.1016/j.renene.2015.01.041.

Macharis, C., Springael, J., De Brucker, K., \& Verbeke, A. (2004). Promethee and AHP: the design of operational synergies in multicriteria analysis: strengthening promethee with ideas of AHP. European Journal of Operational Research, 153(2), 307-317. http://dx.doi.org/10.1016/S0377-2217(03)00153-X.

Madlener, R., Antunes, C. H., \& Dias, L. C. (2009). Assessing the performance of biogas plants with multi-criteria and data envelopment analysis. European Journal of Operational Research, 197(3), 1084-1094. http://dx.doi.org/10.1016/j.ejor.2007.12.051.

Martins, F. R., Guarnieri, R. A., \& Pereira, E. B. (2008). O aproveitamento da energia eólica. Revista Brasileira de Ensino de Física, 30(1), 1-13. http://dx.doi.org/10.1590/S180611172013000100028.

McMichael, A. J., Powles, J. W., Butler, C. D., \& Uauy, R. (2007). Food, livestock production, energy, climate change, and health. Lancet, 370(9594), 1253-1263. http://dx.doi.org/10.1016/S0140-6736(07)61256-2. PMid:17868818.

Pazheri, F. R., Othman, M. F., \& Malik, N. H. (2014). A review on global renewable electricity scenario. Renewable \& Sustainable Energy Reviews, 31, 835-845. http://dx.doi.org/10.1016/j.rser.2013.12.020.

Pereira, M. G., Camacho, C. F., Freitas, M. A. V., \& Silva, N. F. (2012). The renewable energy market in Brazil: current status and potential. Renewable \& Sustainable Energy Reviews, 16(6), 3786-3802. http://dx.doi.org/10.1016/j.rser.2012.03.024. 
Pinto, L. I. C., Martins, F. R., \& Pereira, E. B. (2017). O mercado brasileiro da energia eólica, impactos sociais e ambientais. Revista Ambiente \& Água, 12(6), 1082-1100. http://dx.doi.org/10.4136/ambi-agua.2064.

Pohekar, S., \& Ramachandran, M. (2004). Application of multi-criteria decision making to sustainable energy planning: a review. Renewable \& Sustainable Energy Reviews, 8(4), 365-381. http://dx.doi.org/10.1016/j.rser.2003.12.007.

Portal Multiempreendimentos. (2013). Central geradora Eólica Gargaú. Retrieved in 2017, November 10, from http://multiempreendimentos.com/casos-de-sucesso-gargau.php

Reiche, D., \& Bechberger, M. (2004). Policy differences in the promotion of renewable energies in the EU member states. Energy Policy, 32(7), 843-849. http://dx.doi.org/10.1016/S03014215(02)00343-9.

Rio de Janeiro. Governo do Estado. (2002). Atlas eólico do estado do Rio de Janeiro. Rio de Janeiro: Governo do Estado do Rio de Janeiro.

Rio de Janeiro. Governo do Estado. (2017). Valor da terra nua. Rio de Janeiro: Governo do Estado do Rio de Janeiro.

Rosa, C. S., Gonçalves Júnior, E. R., Souza, C. L. M., \& Erthal Junior, M. (2018). Analysis of the acumulum and disposal method of assets in public organs. Revista Produção $e$ Desenvolvimento, 4(2), 60-75. http://dx.doi.org/10.32358/rpd.2018.v4.259.

Saaty, T. L. (1990). How to make a decision: the analytic hierarchy process. European Journal of Operational Research, 48(1), 9-26. http://dx.doi.org/10.1016/0377-2217(90)90057-I.

Saaty, T. L. (1991). Método de análise hierárquica. São Paulo: McGraw-Hill.

Shinde, D. D., \& Prasad, R. (2017). Application of AHP for ranking of total productive maintenance pillars. Wireless Personal Communications, 100, 449-462. http://dx.doi.org/10.1007/s11277-017-5084-4.

Silva, D. M. R. (2007). Aplicação do método AHP para avaliação de projetos industriais (Dissertação de mestrado). Pontifícia Universidade Católica do Rio de Janeiro, Rio de Janeiro. https://doi.org/10.17771/PUCRio.acad.10385.

Silva, R. C., Marchi Neto, I., \& Seifert, S. S. (2016). Electricity supply security and the future role of renewable energy sources in Brazil. Renewable \& Sustainable Energy Reviews, 59, 328-341. http://dx.doi.org/10.1016/j.rser.2016.01.001.

Simas, M., \& Pacca, S. (2013). Energia eólica, geração de empregos e desenvolvimento sustentável. Estudos Avançados, 27(77), 99-115. http://dx.doi.org/10.1590/S010340142013000100008.

Solangi, Y. A., Tan, Q., Khan, M. W. A., Mirjat, N. H., \& Ahmed, I. (2018). The selection of wind power project location in the southeastern corridor of Pakistan: a factor analysis, AHP, and Fuzzy-TOPSIS application. Energies, 11(8), 1940. http://dx.doi.org/10.3390/en11081940.

Souza, L. P., Gomes, C. F. S., \& Barros, A. P. (2018). Implementation of new Hybrid AHPTOPSIS-2N method in sorting and prioritizing of an it CAPEX project portfolio. International Journal of Information Technology \& Decision Making, 17(4), 977-1005. http://dx.doi.org/10.1142/S0219622018500207.

Sun, H., Wang, S., \& Hao, X. (2017). An Improved Analytic Hierarchy Process Method for the evaluation of agricultural water management in irrigation districts of north China.

Agricultural Water Management, 179(1), 324-337.

http://dx.doi.org/10.1016/j.agwat.2016.08.002.

Vargas, R. (2010). Utilizando a Programação Multicritério (AHP) para selecionar e priorizar projetos na gestão de portfólio. In Proceedings of the PMI Global Congress 2010 - North America. Washington: Project Management Institute.

Watson, J. J. W., \& Hudson, M. D. (2015). Regional scale wind farm and solar farm suitability assessment using GIS-assisted multi-criteria evaluation. Landscape and Urban Planning, 138, 20-31. http://dx.doi.org/10.1016/j.landurbplan.2015.02.001. 
Wolsink, M. (2000). Wind power and the NIMBY-myth: institutional capacity and the limited significance of public support. Renewable Energy, 21(1), 49-64. http://dx.doi.org/10.1016/S0960-1481(99)00130-5.

Yunna, W., \& Geng, S. (2014). Multi-criteria decision making on selection of solar-wind hybrid power station location: A case of China. Energy Conversion and Management, 81, 527533. http://dx.doi.org/10.1016/j.enconman.2014.02.056.

Zahir, S. (1999). Clusters in group: decision making in the vector space formulation of the analytic hierarchy process. European Journal of Operational Research, 112(3), 620-634. http://dx.doi.org/10.1016/S0377-2217(98)00021-6.

Żak, J., \& Galińska, B. (2018). Multiple criteria evaluation of suppliers in different industriescomparative analysis of three case studies. Advances in Intelligent Systems and Computing, 572, 121-155. http://dx.doi.org/10.1007/978-3-319-57105-8_6. 